\section{FDA backs off attempt to control private DNA research}

THE US Food and Drug Administration has concluded that it probably lacks the legal authority to regulate recombinant DNA research in private industry, as it had previously announced its intention to do following a directive from Health Secretary Joseph A Califano last December.

Instead, the FDA plans to encourage companies to comply voluntarily with the guidelines that have been established by the National Institutes of Health for federally-funded research. The NIH is itself recommending some amendments to the guidelines to make them more acceptable to industry.

Two weeks ago, however, the NIH's Recombinant DNA Advisory Committee passed a resolution recommending that private industry be legally required to observe the guidelines. It is now up to $\mathrm{Mr}$ Califano to decide whether a scheme of voluntary compliance is adequate, or whether to seek another route for regulation-possibly involving a new legislative initiative

Following the failure of numerous attempts in the past to extend the NIH guidlelines to industry, Dr Fredrickson, director of NIH, announced last year that companies would be able to register with the NIH-if they wished - to have containment levels for proposed experiments approved.

So far, however, companies have been reluctant to register, fearing that compliance with some sections of the guidelines would require them to divulge commercially-sensitive information. At least one companyGenentech, in San Francisco-is now conducting experiments with 60 litres of culture which would have required submitting full details to the RAC for a special exemption from prohibition under current NIH procedures.

The NIH is now proposing to add a new section to the guidelines to meet such fears. For example, although academic scientists wishing to have a new host-vector system approved by the director of $\mathrm{NIH}$ make available full details of the system and its proposed use, this would be waived for private companies, who say it could require disclosing commercial secrets.

Under the proposed addition to the guidelines, private companies would set up their own institutional biohazard committees. But members of such committees would be exempt from the requirement that they should not be involved in approving a project in which they had a financial interest.

The NIH has also gone to some lengths to establish that it would be a criminal act for any member of the $\mathrm{RAC}$, as "temporary government employees", to divulge confidential commercial information submitted to the committee, and that this information would therefore be immune to the Freedom of Information Act.

At a meeting with HEW general counsel $\mathrm{Mr}$ Peter Libassi last week, industry representatives said they were reasonably happy with the new proposals as a basis for voluntary compliance. Public interest and labour representatives, however, were adamant that a voluntary system would not work and that some form of legal back-up was necessary. They also urged that the Environmental Protection Agency and the Occupational Safety and Health Administration take a more active role.

The position on legal controls has been complicated by the FDA's decision. Last December, coinciding with the publication of a revised version of the guidelines and following a directive from $\mathrm{Mr}$ Califano, the FDA published a "notice of intent" to introduce regulations. These would require a firm submitting a product

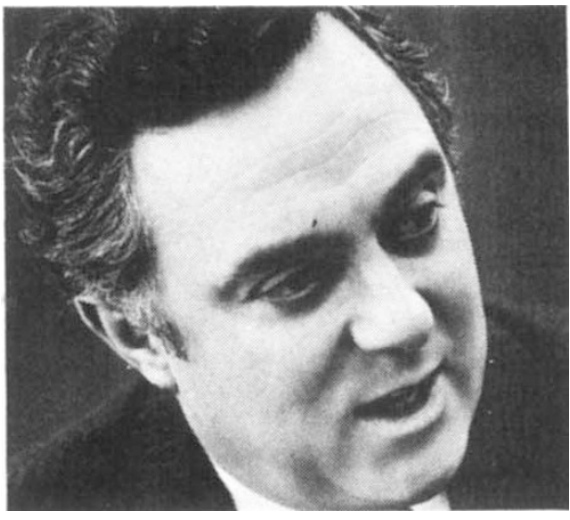

Califano: he must decide

for licensing by the FDA to demonstrate that any recombinant DNA research carried out in connection with the product had been done in accordance with the NIH guidelines.

Pharmaceutical companies, however, challenged whether the FDA had the authority to do this under the terms of the federal Food Drug and Cosmetic Act, claiming that the agency's authority was restricted to clinical trials and marketing.

Dr C. W. Pettinga, executive vicepresident of Eli Lilly and Company, commented: "In our view the proposal must be carefully evaluated because it could evolve into the regulation of basic research, an undesirable ciroumstance from a public policy standpoint and clearly not warranted in view of the experience with recombinant DNA technology."

No public reply has yet been made by the FDA. But in the light of these and similar comments, officials in the agency confirmed last week that the proposal to introduce new regulations had been dropped and that support was being recommended for the voluntary compliance scheme as being proposed by the NIH.

Dr Fredrickson is now expected to forward these comments, as well as both the NIH's proposals and the RAC resolution, to $\mathrm{Mr}$ Califano-who will have to decide how to take things from there.

David Dickson

\title{
Plan for early warning on social effects of biomedical advances
}

ThE National Commission for the Protection of Human Subjects, a body set up in 1974 to study the ethical, social and legal implications of advances in biomedical and behavioural research and technology, has recommended setting up an advisory commission "to anticipate the probable effects of research and technological advances for individuals and society, and to stimulate public participation in decision-making".

This recommendation has arisen from a special study conducted by the commission, whose conclusions were published in the Federal Register last week. The commission says that the results of the study showed both a perceived need for a programme to assess the social impact of technology, and a need to facilitate public information and public participation in research and technological innovations and the policy decisions that result.

"These findings suggest that a mechanism should be established to monitor and evaluate innovations and to provide an early warning system in which the probable effect of innovations in biomedical and behavioural research and technology can be assessed publicly, prior to develop- ment of widespread dissemination", the commission says. Existing entities, such as those attached to the National Academy of Sciences or the National Institutes of Health, served narrower constituencies and goals, and the independence and broader mandate of a new body were needed, it says.

"The commission should not be dominated by health professionals, for its main purpose would be to facilitate widespread debate involving all segments of society in the ethical and policy issues that affect all people and about which diverse views should be heard." 